\title{
EVALUATION OF PASSIVE DIFFUSION BAG SAMPLERS IN SELECTED WELLS AT THE NAVAL SURFACE WARFARE CENTER, LOUISVILLE, KENTUCKY, JULY 1999 TO JANUARY 2000
}

Water Resources Investigations Report 01-4163

Prepared in cooperation with the

SOUTHERN DIVISION NAVAL FACILITIES ENGINEERING COMMAND 


\section{Evaluation of Passive Diffusion Bag Samplers in Selected Wells at the Naval Surface Warfare Center, Louisville, Kentucky, July 1999 to January 2000}

By Don A. Vroblesky, Matthew D. Petkewich, and Clifton C. Casey

U.S. Geological Survey

Water Resources Investigations Report 01-4163

Prepared in cooperation with the

SOUTHERN DIVISION NAVAL FACILITIES ENGINEERING COMMAND

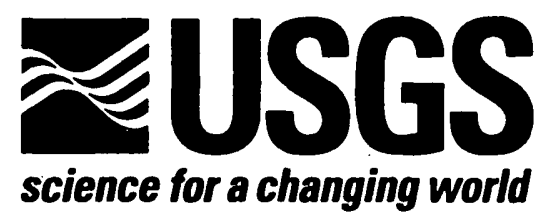

Columbia, South Carolina 2001 


\section{U.S. DEPARTMENT OF THE INTERIOR \\ GALE A. NORTON, Secretary}

U.S. GEOLOGICAL SURVEY

Charles G. Groat, Director

Use of trade, product, or firm names in this publication is for descriptive purposes only and does not imply endorsement by the U.S. Geological Survey

For additional information

Copies of this report can be write to:

purchased from:

District Chief

U.S. Geological Survey

720 Gracern Road

Columbia, SC 29210-7651

U.S. Geological Survey

Branch of Information Services

Box 25286

Denver, CO 80225

888-ASK-USGS

Additional information about water resources in South Carolina is available on the World Wide Web at http://sc.water.usgs.gov 


\section{CONTENTS}

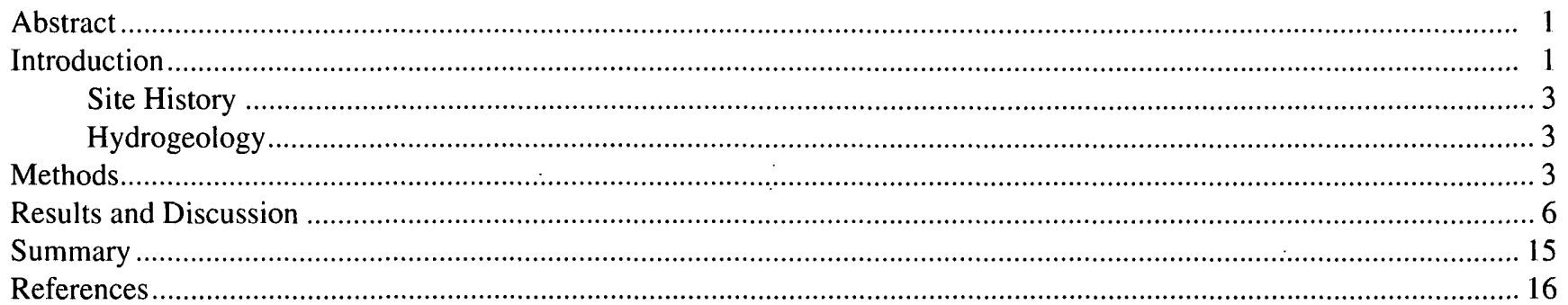

\section{FIGURES}

1. Map showing location of observation wells used in this investigation at the Naval Surface Warfare Center, Louisville, Kentucky.....

2. Graph showing comparison of benzene, toluene, ethyl benzene, and total xylenes concentrations in passive diffusion bag samplers and in pumped samples, well 1-NW-MW24-S, Naval Surface Warfare Center, Louisville, Kentucky, January 2000

\section{TABLES}

1. Well-construction and passive diffusion bag sampler information for wells used in this investigation, Naval Surface Warfare Center, Louisville, Kentucky.....

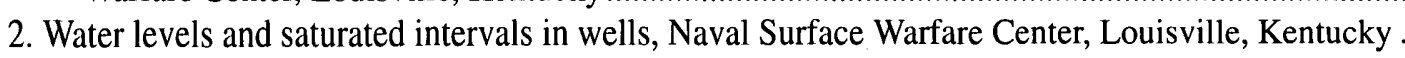
4

3. Summary of passive diffusion bag sampler results, Naval Surface Warfare Center, Louisville, Kentucky..... 5

4. Comparison of volatile organic compound concentrations in passive diffusion bag samples and pumped samples, September 1999 and January 2000, and historical sampling results, Naval Surface Warfare Center, Louisville, Kentucky 


\section{CONVERSION FACTORS, ABBREVIATIONS, ACRONYMS, AND VERTICAL DATUM}

\begin{tabular}{|c|c|c|}
\hline \multirow{2}{*}{\multicolumn{3}{|c|}{$\frac{\text { Multiply }}{\text { 2. }}$}} \\
\hline & & \\
\hline inch (in.) & 25.4 & millimeter \\
\hline foot $(\mathrm{ft})$ & 0.3048 & meter \\
\hline mile (mi) & 1.609 & kilometer \\
\hline \multirow{3}{*}{ gallon (gal) } & Volume & \\
\hline & 3.785 & liter \\
\hline & Flow & \\
\hline foot per day (ft/d) & 0.3048 & meter per day \\
\hline foot per year $(\mathrm{ft} / \mathrm{yr})$ & 0.3048 & meter per year \\
\hline
\end{tabular}

\begin{tabular}{r|l}
\hline$\mu \mathrm{L}$ & liter \\
$\mathrm{mL}$ & microgram \\
milliliter \\
BRAC & Base Realignment and Closure Program \\
LNAPL & light non-aqueous phase liquid \\
LDPE & low-density polyethylene \\
MTBE & methyl-tert-butyl ether \\
NSWC & Naval Surface Warfare Center \\
PDB & passive diffusion bag \\
USGS & U.S. Geological Survey \\
VOA & volatile organic analysis \\
VOC & volatile organic compound \\
\hline
\end{tabular}

Chemical concentration: In this report, chemical concentration in water is expressed in metric units as milligrams per liter $(\mathrm{mg} / \mathrm{L})$ or micrograms per liter $(\mu \mathrm{g} / \mathrm{L})$.

Sea level: In this report, "sea level" refers to the National Geodetic Vertical Datum of 1929 (NGVD of 1929)a geodetic datum derived from a general adjustment of the first-order level nets of the United States and Canada, formerly called Sea Level Datum of 1929. 


\title{
Evaluation of Passive Diffusion Bag Samplers in Selected Wells at the Naval Surface Warfare Center, Louisville, Kentucky, July 1999 to January 2000
}

\author{
By Don A. Vroblesky ${ }^{1}$, Matthew D. Petkewich ${ }^{1}$, and Clifton C. Casey²
}

\begin{abstract}
Passive diffusion bag samplers were tested in 11 wells at the Naval Surface Warfare Center, Louisville, Kentucky, by comparing the volatile organic compound concentrations obtained from passive diffusion bag samplers to volatile organic compound concentrations obtained by pumping the wells. The wells were screened in poorly permeable formations, including overburden, shale, and limestone. In five of the tested wells containing detectable volatile organic compound contamination, the data suggest that the diffusion samplers accurately reflected ambient contaminant concentrations (wells 1-NEC-15-P, 1-NEC-MW17-S, 1-NEMW23-S, 1-NW-MW24-S, and 1-NW-MW24-P). Comparison of a third well (1-NEC-MW34-S), in which the passive diffusion bag samplers produced higher concentrations than the pumped sample, is less certain because the passive diffusion bag sampler had passed through a layer of light non-aqueous phase liquid during deployment, suggesting the possibility of carryover contamination. In two wells (1-NE-MW23-P and 1-NEC-MW15-S), it was unclear whether concentrations obtained by using the passive diffusion bag samplers adequately represented in situ concentrations because the comparison of concentrations obtained by
\end{abstract}

\footnotetext{
'U.S. Geological Survey, Columbia, S.C.

${ }^{2}$ Southern Division Naval Facilities Engineering Command, Charleston, S.C.
}

using the samplers and the pump was inconsistent between sampling events and/or between volatile organic compounds. In one well (1-NEC-MW34-P), the methodologies matched poorly, with volatile organic compound concentrations obtained by using the passive diffusion bag sampler substantially lower than those obtained by using the pump. Two of the tested wells (1-NW-MW6-I and 1-SE-MW13-I) contained no detectable contaminants in water obtained from either method.

Data from wells where multiple passive diffusion bag samplers were deployed showed the lowest volatile organic compound concentrations adjacent to the vuggy limestone and higher volatile organic compound concentrations deeper in the limestone, supporting colloidal-borescope data that indicate the vuggy limestone is not a zone that supplies water to the wells.

\section{INTRODUCTION}

Ground-water contamination by a variety of compounds is present at the Naval Surface Warfare Center (NSWC), also known as the Naval Ordnance Station, Louisville, Ky. (fig. 1). The facility is part of the U.S. Department of Defense Base Realignment and Closure (BRAC) program. The NSWC is on approximately 144 acres within the southern limits 


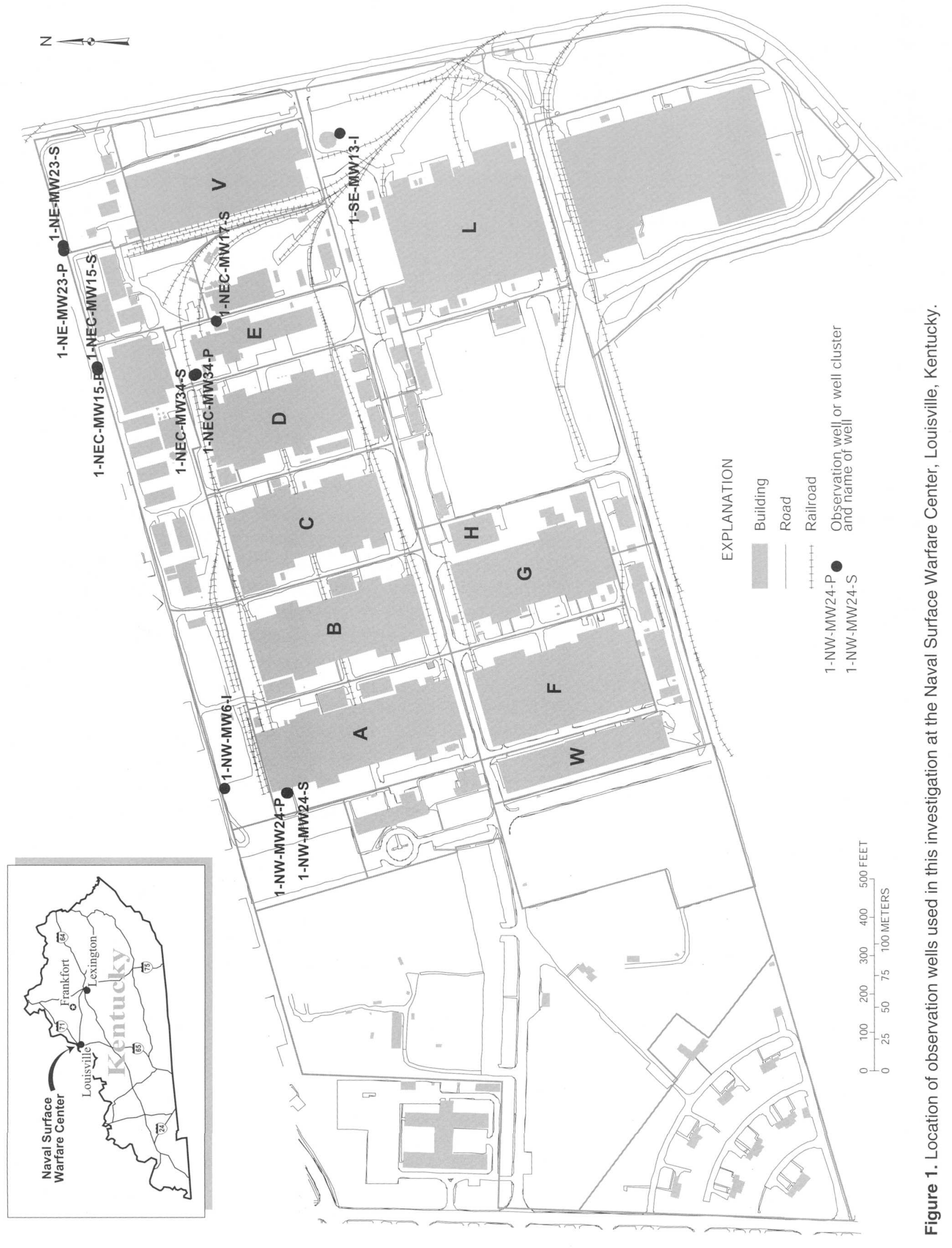


of Louisville, Jefferson County, approximately 7 miles (mi) south of downtown Louisville, and approximately $1 \mathrm{mi}$ west of Louisville International Airport.

The U.S. Geological Survey (USGS), in cooperation with the U.S. Department of the Navy, Southern Division Naval Facilities Engineering Command, investigated the potential for use of low-density polyethylene (LDPE) passive diffusion bag (PDB) samplers (Vroblesky and Hyde, 1997) as an alternative methodology for collecting ground-water volatile organic compound (VOC) samples. The standard technique used at the site to collect ground-water samples is a pumping method using purge-and-sample technology. The investigation involved side-by-side comparisons of contaminant concentrations obtained by using PDB samplers to concentrations obtained by using groundwater pumps in 11 wells. This reports presents the findings of that investigation.

\section{Site History}

Since 1941, the NSWC has manufactured, overhauled, and produced weapons systems needed by combat vessels of the U.S. Navy. Various hazardous chemicals, including petroleum hydrocarbons, have been released to the soil and ground water as a result of past disposal activities and accidental spills and releases. At least three sumps may have breached a shale confining unit separating the shallow overburden water-bearing zone from the underlying limestone aquifer. Free-phase petroleum was found in the limestone aquifer at several locations on the facility, as well as at Auburndale, Ky., approximately $1.5 \mathrm{mi}$ south of the facility (Charles J. Taylor, U.S. Geological Survey, written commun., 1996). Hydrocarbon characterization (fingerprinting) showed the petroleum to be crude oil (Environmental Liability Management, Inc, 1999), and its widespread occurrence suggests a natural source.

\section{Hydrogeology}

The site hydrogeology has been investigated extensively by consultants and the U.S. Geological Survey (Charles J. Taylor, U.S. Geological Survey, written commun., 1996). Unless otherwise noted, all information contained in this section is derived from Tetra Tech NUS, Inc. (2000).
The subsurface at NSWC Louisville is characterized by a shallow overburden, ranging in thickness from about $7 \mathrm{feet}(\mathrm{ft})$ in the eastern and northeastern part of the facility to about $30 \mathrm{ft}$ in the western and southwestern part of the facility. The sediment consists predominantly of clays and silty clay with lesser amounts of sand and gravel. In most places at the facility, the overburden is underlain by an organic shale confining unit, averaging about $10 \mathrm{ft}$ thick and locally absent in the extreme western and southwestern areas of the facility. Limestone underlies the shale and overburden. A 1- to 5-ft thick vuggy zone of moldic porosity is present in the upper part of the limestone, approximately $1 \mathrm{ft}$ below the shale contact, and the zone is stained with crude oil in parts of the facility as well as in some offsite wells (Charles J. Taylor, U.S. Geological Survey, written commun., 1996). Colloidal borescope measurements in the wells implied that the vuggy zone does not transmit water (Aqua VISION, 1999).

In general, all of the strata are poorly permeable. The overburden is composed of clay to silty clay. The average horizontal hydraulic conductivity of the overburden, based on slug tests, is approximately 1.6 feet per day $(\mathrm{ft} / \mathrm{d})$, and these data in combination with measured hydraulic gradients and estimated porosity, imply that the ground-water velocity is about 1.46 to 3.28 feet per year (ft/yr). Although no aquifer tests were done in the shale, the lithology, sparseness of fractures, and literature values for hydraulic conductivity suggest a seepage velocity of about $0.12 \mathrm{ft} / \mathrm{yr}$. Bedrock packer tests in the limestone showed average horizontal hydraulic conductivities ranging from $1.3 \times 10^{-1}$ to $1 \times 10^{-3} \mathrm{ft} / \mathrm{d}$.

\section{METHODS}

Ground-water samples were collected from 11 wells (fig. 1) to compare VOC results obtained from PDB samplers to results obtained by purging and sampling the wells (table 1). PDB samplers used in the wells consisted of a 1.5-inch (in.)-diameter low-density polyethylene (LDPE) tube heat-sealed at both ends and containing deionized water. The samplers were deployed and recovered for two separate sampling events. During the first sampling event, samplers were deployed in July and recovered in September 1999. During the second sampling event, samplers were deployed in two wells in September and in five wells in December 1999 
Table 1. Well-construction and passive diffusion bag sampler information for wells used in this investigation, Naval Surface Warfare Center, Louisville, Kentucky

\begin{tabular}{|c|c|c|c|c|c|c|c|c|}
\hline Well & Zone & $\begin{array}{l}\text { Well } \\
\text { depth } \\
\text { (feet) }\end{array}$ & $\begin{array}{c}\text { Well } \\
\text { diameter } \\
\text { (inches) }\end{array}$ & $\begin{array}{c}\text { Screen } \\
\text { length } \\
\text { (feet) }\end{array}$ & $\begin{array}{l}\text { Number of } \\
\text { samplers } \\
\text { installed }\end{array}$ & $\begin{array}{l}\text { Date } \\
\text { deployed }\end{array}$ & $\begin{array}{l}\text { Date } \\
\text { recovered }\end{array}$ & $\begin{array}{c}\text { Days of } \\
\text { equilibration }\end{array}$ \\
\hline 1-NEC-MW15-P & Overburden & 12.78 & 4 & 5 & 1 & $7 / 28 / 99$ & $9 / 22 / 99$ & 56 \\
\hline \multirow[t]{2}{*}{ 1-NE-MW23-P } & Overburden & 11.17 & 4 & 5 & 1 & $7 / 28 / 99$ & $9 / 20 / 99$ & 54 \\
\hline & & & & & 1 & $12 / 15 / 99$ & $1 / 11 / 00$ & 27 \\
\hline 1-NW-MW24-P & Overburden & 11.93 & 4 & 5 & 1 & $7 / 28 / 99$ & $9 / 21 / 99$ & 55 \\
\hline \multirow[t]{2}{*}{ 1-NEC-MW34-P } & Overburden & 10.4 & 4 & 5 & 1 & $7 / 28 / 99$ & $9 / 23 / 99$ & 57 \\
\hline & & & & & 1 & $12 / 15 / 99$ & $1 / 12 / 00$ & 28 \\
\hline \multirow[t]{2}{*}{ 1-NW-MW6-I } & Shale & 17.97 & 2 & 3 & 1 & $7 / 8 / 99$ & $9 / 22 / 99$ & 56 \\
\hline & & & & & 2 & $12 / 15 / 99$ & $1 / 12 / 00$ & 28 \\
\hline 1-SE-MW13-I & Shale & 21.56 & 2 & 5 & 1 & $7 / 28 / 99$ & $9 / 23 / 99$ & 56 \\
\hline \multirow[t]{2}{*}{ 1-NEC-MW15-S } & Limestone & 40.64 & 4 & 10 & 1 & $7 / 28 / 99$ & $9 / 22 / 99$ & 56 \\
\hline & & & & & 2 & $9 / 23 / 99$ & $1 / 12 / 00$ & 111 \\
\hline 1-NEC-MW17-S & Limestone & 38.68 & 4 & 10 & 1 & $7 / 28 / 99$ & 9/23/99 & 57 \\
\hline \multirow[t]{2}{*}{ 1-NE-MW23-S } & Limestone & 45.13 & 4 & 20 & 1 & $7 / 28 / 99$ & $9 / 21 / 99$ & 55 \\
\hline & & & & & 3 & 9/23/99 & $1 / 11 / 00$ & 110 \\
\hline \multirow[t]{2}{*}{ 1-NW-MW24-S } & Limestone & 37.77 & 4 & 15 & 1 & $7 / 28 / 99$ & 9/21/99 & 55 \\
\hline & & & & & 3 & $12 / 15 / 99$ & $1 / 11 / 00$ & 27 \\
\hline 1-NEC-MW34-S* & Limestone & 38.26 & 4 & 15 & 1 & $12 / 15 / 99$ & $1 / 12 / 00$ & 28 \\
\hline
\end{tabular}

* Contained light non-aqueous-phase liquid.

with all samplers recovered in January 2000. A LDPE mesh placed on the outside of the samplers provided protection against abrasion. The samplers were positioned at the target horizons by attachment to a nylon weighted line. Target horizons were chosen to coincide with geologic features, such as the vuggy zone, to approximate the center of a saturated interval or to provide vertical distribution data.

Samplers were recovered by using the attached weighted line. Water was removed from the diffusion sampler by cutting it open and gently pouring the water contents into 40 -milliliter $(\mathrm{mL})$ volatile organic analysis (VOA) vials, making sure that no headspace remained. Water in the vials was preserved with hydrochloric acid to lower the $\mathrm{pH}$ to approximately 2 , and the samplers were then stored on ice. Chemical analyses were conducted at a commercial laboratory using U.S. Environmental Protection Agency Method 8260b (U.S. Environmental Protection Agency, 1999).
During the first test (September 1999), the USGS purged and sampled nine wells immediately following recovery of the PDB samplers. Very slow purging [less than 80 milliliters per minute $(\mathrm{mL} / \mathrm{min})$ ] with a peristaltic pump removed nearly all the water in wells 1-NE-MW23-P, 1-NW-24-P, 1-NEC-17-S, 1-NEC-15-P, and 1-NEC-34-P; the wells were allowed to partially recover prior to collecting the samples. Each well was sampled by pumping a water sample from the target horizon with a peristaltic pump or a Bennett positive-displacement pump.

The remaining four tested wells 1-NE-MW23S, 1-NW-MW24-S, 1-NEC-MW15-S, and 1-SEMW13-I were not completely purged during the first test in an attempt to obtain water in the direct vicinity of the diffusion samplers. Well 1-NE-MW23-S was purged at a low rate (approximately 100 $\mathrm{mL} / \mathrm{min}$ ) for 30 minutes, and the pump was turned off. Well 1NE-MW23-S was allowed to recover for 
2 hours, and water was collected from the vicinity of the sampler by using a peristaltic pump. The pumped samples from well 1-NW-MW24-S were collected after purging for 20 minutes with less than $0.1 \mathrm{ft}$ of drawdown, within 2 hours following PDB-sampler recovery. The well was sampled by using a Bennett pump because the depth to water exceeded the peristaltic pump capacity.

\section{Wells 1-NEC-MW15-S and 1-SE-MW13-I also} were sampled after purging at a low rate for 30 minutes. The aquifer at well 1-NEC-MW15-S was very poorly permeable. After pumping the well slowly $(78 \mathrm{~mL} / \mathrm{min})$ for 1 hour and 42 minutes, virtually all the pumped water continued to come from well storage, as determined by comparing the calculated change in water volume within the well to the measured volume of water pumped out of the well. The pumping rate was increased, lowering the water level in the well a total of $22 \mathrm{ft}$. The pump was then turned off, and the well was allowed to remain undisturbed for 1 hour and $17 \mathrm{~min}$ utes; however, the water level showed no change. Thus, the sampling data indicated that the well is poorly connected to the aquifer, and water samples collected from this well 1-NEC-MW15-S by the purge-and-sample method, should be regarded as questionable. Similarly, most of the water pumped from well 1-SE-MW13-I seems to have been from aquifer storage.
During the second test, a commercial contractor sampled the wells within 1 or 2 days of PDB-sampler recovery by the USGS. Well purging was accomplished by using a 2 -in. diameter submersible positive-displacement pump for the recharging bedrock wells or a disposable bailer for the low-volume shallow wells or lowyielding deeper wells. The samples were collected after evacuating the well casing or after purging three casing volumes of water by using a pump or bailer. The water samples obtained using PDB samplers were shipped with and analyzed by the same laboratory as the samples collected by the conventional approach for each well.

In five of the tested wells (1-NEC-MW17-S, 1-NEC-MW15-P, 1-NW-MW24-P, and 1-NEC-

MW34-P), the length of the saturated water column within the well screen was less than $3 \mathrm{ft}$ (table 2). Wells having short saturated intervals are of concern because of the potential for the PDB samplers to be exposed above the water column.

PDB sampler data showed a close match between replicate samples. The PDB sampler at well 1-NECMW23-S showed concentrations [53 micrograms per liter $(\mu \mathrm{g} / \mathrm{L})$ benzene, $18 \mu \mathrm{g} / \mathrm{L}$ toluene, $9 \mu \mathrm{g} / \mathrm{L}$ 2-butanone, $18 \mu \mathrm{g} / \mathrm{L}$ ethyl benzene, and $42 \mu \mathrm{g} / \mathrm{L}$ total xylenes] equal to or within a few micrograms per liter of concentrations obtained from a duplicate sample collected from the same sampler $(54 \mu \mathrm{g} / \mathrm{L}$ benzene, $18 \mu \mathrm{g} / \mathrm{L}$ toluene, $9 \mu \mathrm{g} / \mathrm{L}$ 2-butanone, $17 \mu \mathrm{g} / \mathrm{L}$ ethyl benzene, and $39 \mu \mathrm{g} / \mathrm{L}$ total xylenes).

Table 2. Water levels and saturated intervals in wells, Naval Surface Warfare Center, Louisville, Kentucky

[Depth to water is below top of casing; NS, no sample]

\begin{tabular}{|l|c|c|c|c||c||c|}
\hline \multirow{2}{*}{ Well } & \multicolumn{3}{|c|}{ September 1999 } & \multicolumn{3}{|c|}{ January 2000 } \\
\cline { 2 - 7 } & $\begin{array}{c}\text { Depth } \\
\text { to } \\
\text { water } \\
\text { (feet) }\end{array}$ & $\begin{array}{c}\text { Length of } \\
\text { water } \\
\text { column } \\
\text { in well } \\
\text { (feet) }\end{array}$ & $\begin{array}{c}\text { Saturated } \\
\text { screen } \\
\text { interval } \\
\text { (feet) }\end{array}$ & $\begin{array}{c}\text { Depth } \\
\text { to } \\
\text { water } \\
\text { (feet) }\end{array}$ & $\begin{array}{c}\text { Length of } \\
\text { water } \\
\text { column } \\
\text { in well } \\
\text { (feet) }\end{array}$ & $\begin{array}{c}\text { Saturated } \\
\text { screen } \\
\text { interval } \\
\text { (feet) }\end{array}$ \\
\hline 1-NEC-MW15-P & 11.09 & 1.69 & 1.69 & NS & NS & NS \\
1-NE-MW23-P & 5.98 & 5.19 & 5 & 6.28 & 4.89 & 4.89 \\
1-NW-MW24-P & 10.88 & 1.05 & 1.05 & NS & NS & NS \\
1-NEC-MW34-P & 7.75 & 2.65 & 2.65 & 7.57 & 2.83 & 2.83 \\
1-NW-MW6-I & NS & NS & NS & 7.07 & 10.9 & 3 \\
1-NEC-MW15-S & NS & NS & NS & 18.07 & 22.57 & 10 \\
1-SE-MW13-I & 6.93 & 14.63 & 5 & NS & NS & NS \\
1-NEC-MW17-S & 37.37 & 1.31 & 1.31 & NS & NS & NS \\
1-NE-MW23-S & 10.94 & 34.19 & 20 & 9.91 & 35.22 & 20 \\
1-NW-MW24-S & 23.01 & 14.76 & 14.76 & 20.7 & 17.07 & 15 \\
1-NEC-MW34-S & NS & NS & NS & 5.82 & 32.44 & 15 \\
\hline
\end{tabular}

* Data from Tetra Tech NUS, Inc. (2000). 


\section{RESULTS AND DISCUSSION}

Most of the tested horizons at NSWC Louisville were low yielding. In general, caution should be exercised when sampling low-yielding aquifers by conventional methods or by the PDB-sampler method. When using a pump, if the pumping rate exceeds the recharge rate, then part of the pumped water is from well storage rather than directly from the formation. Moreover, there is potential for volatilization losses by trickling flow if the well is pumped until the water level declines below sources of contaminated-water recharge and then allowed to recover before sampling. When using the PDB method in a low-yielding aquifer, caution should be exercised because of the potential that the rate of volatilization loss in the wellbore may exceed the rate of VOC inflow to the wellbore from the aquifer. Despite the low yield, however, several of the tested wells showed a good comparison between VOC concentrations obtained from the PDB samplers and VOC concentrations obtained by using a pump (table 3)
The comparison between the two methods was considered acceptable if the concentrations for particular contaminants agreed within $10 \mu \mathrm{g} / \mathrm{L}$, or within 10 percent, or the concentration in the PDB sample was higher than in the pumped sample. Five of the tested wells (wells 1-NEC-15-P, 1-NEC-MW17-S, 1-NEMW23-S, 1-NW-MW24-S, and 1-NW-MW24-P) contained detectable contamination and showed a relation between the PDB-sampler results and the pumpedsample results for most compounds, suggesting that the PDB samplers accurately reflected ambient contaminant concentrations.

The PDB-sampler concentrations differed from the pumped sample concentrations by only $3 \mu \mathrm{g} / \mathrm{L}$ or less in well 1-NEC-MW15-P. At well 1-NEC-MW17-S, the PDB-sample toluene concentration differed from the pumped-sample toluene concentration by only $3 \mu \mathrm{g} / \mathrm{L}$, and the PDB-sample benzene concentration was slightly higher than the pumped-sample benzene concentration (table 4), implying that the PDB sample accurately reflected ambient concentrations in the adjacent aquifer.

Table 3. Summary of passive diffusion bag (PDB) sampler results, Naval Surface Warfare Center, Louisville, Kentucky [VOCs, volatile organic compounds; LNAPL, light non-aqueous phase liquid]

\begin{tabular}{|c|c|c|}
\hline Well & $\begin{array}{l}\text { Does PDB } \\
\text { sampler seem to } \\
\text { reflect formation } \\
\text { concentrations? }\end{array}$ & Comments \\
\hline 1-NEC-MW15-P & Yes & \\
\hline 1-NE-MW23-P & Uncertain & Probable redox stratification. \\
\hline 1-NW-MW24-P & Yes & \\
\hline 1-NEC-MW34-P & No & $\begin{array}{l}\text { Possible explanations include (1) partial exposure of the PDB sampler above the water; } \\
\text { (2) volatilization losses in the wellbore; (3) discreet-zone contaminant source. Further } \\
\text { investigation is needed before relying on PDB samplers in this well. }\end{array}$ \\
\hline 1-NW-MW6-I & Yes & No VOCs detected. \\
\hline 1-SE-MW13-I & Yes & No VOCs detected. \\
\hline 1-NEC-MW15-S & Uncertain & $\begin{array}{l}\text { Good match for most compounds, but poor match for total xylenes. Possible explanations } \\
\text { include (1) neither conventional nor PDB samplers adequately reflect formation concentra- } \\
\text { tions in this low-yielding well; (2) PDB samplers may not have fully characterized stratifica- } \\
\text { tion because they only covered } 5 \text { feet of the } 10 \text {-foot well screen; (3) the depths of maximum } \\
\text { total xylene and maximum total chlorinated solvent concentrations may not coincide. }\end{array}$ \\
\hline 1-NEC-MW17-S & Yes & \\
\hline 1-NE-MW23-S & Yes & \\
\hline 1-NW-MW24-S & Yes & \\
\hline 1-NEC-MW34-S & Uncertain & PDB sampler passed through LNAPL during deployment. \\
\hline
\end{tabular}




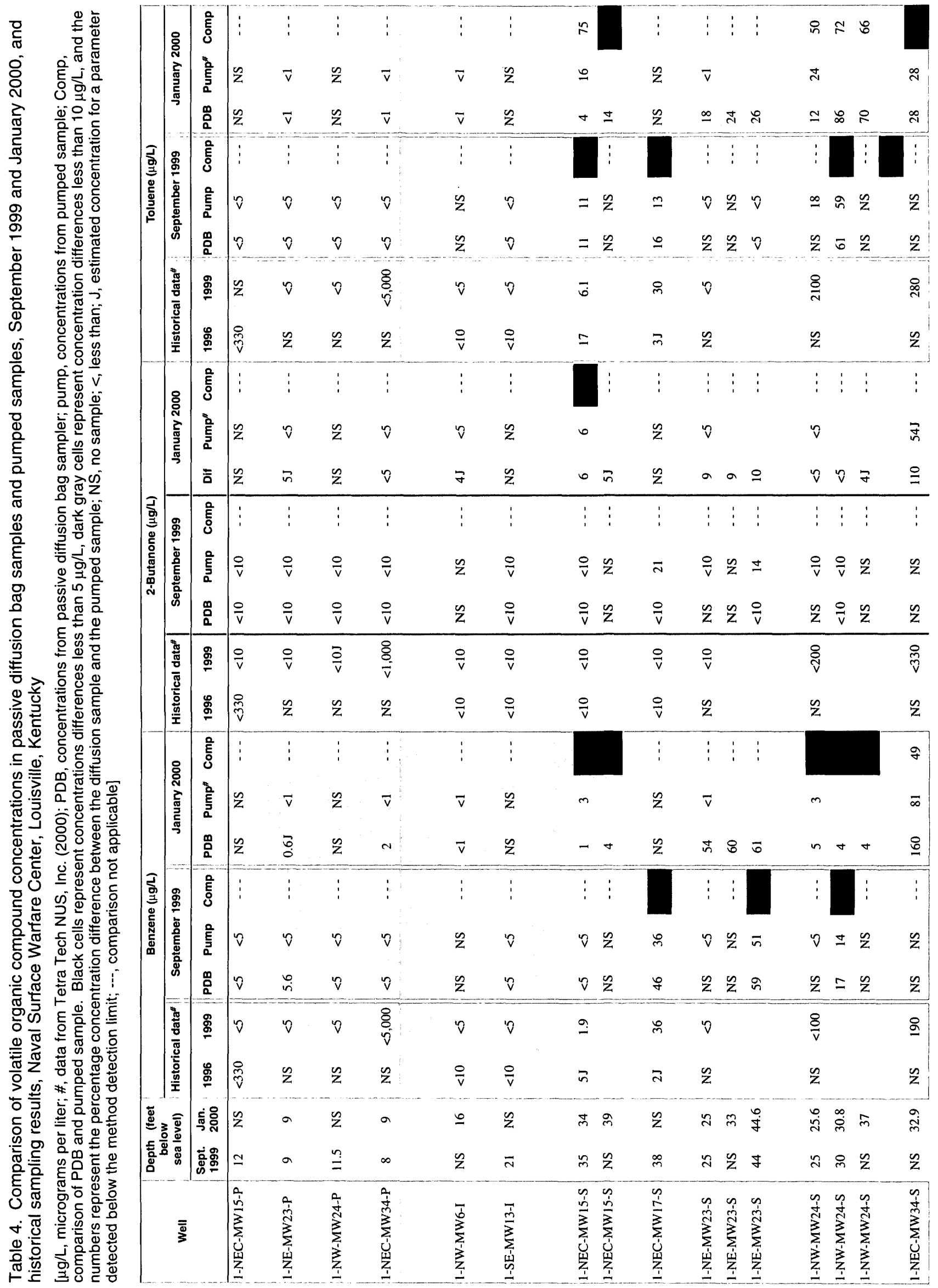




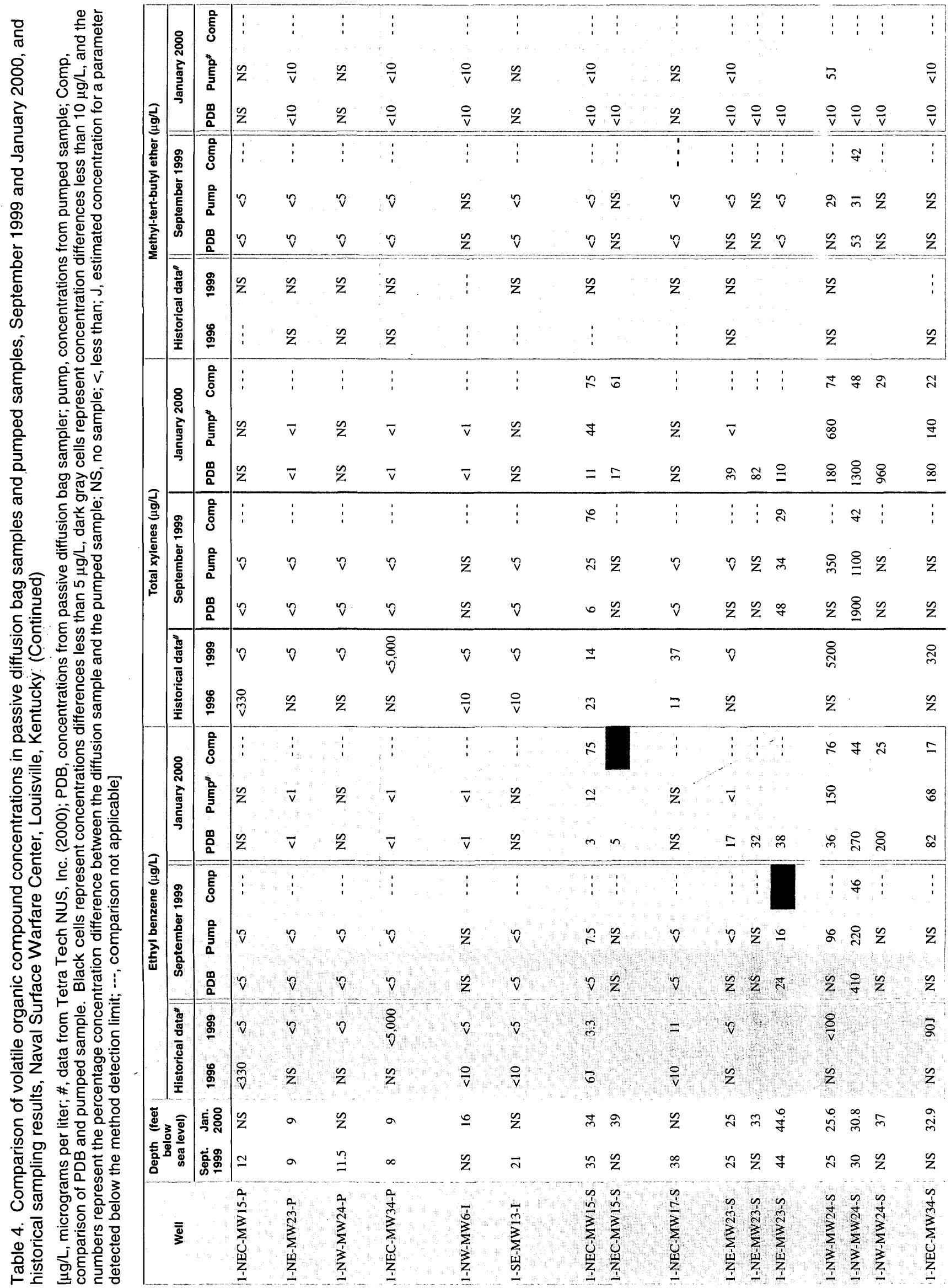




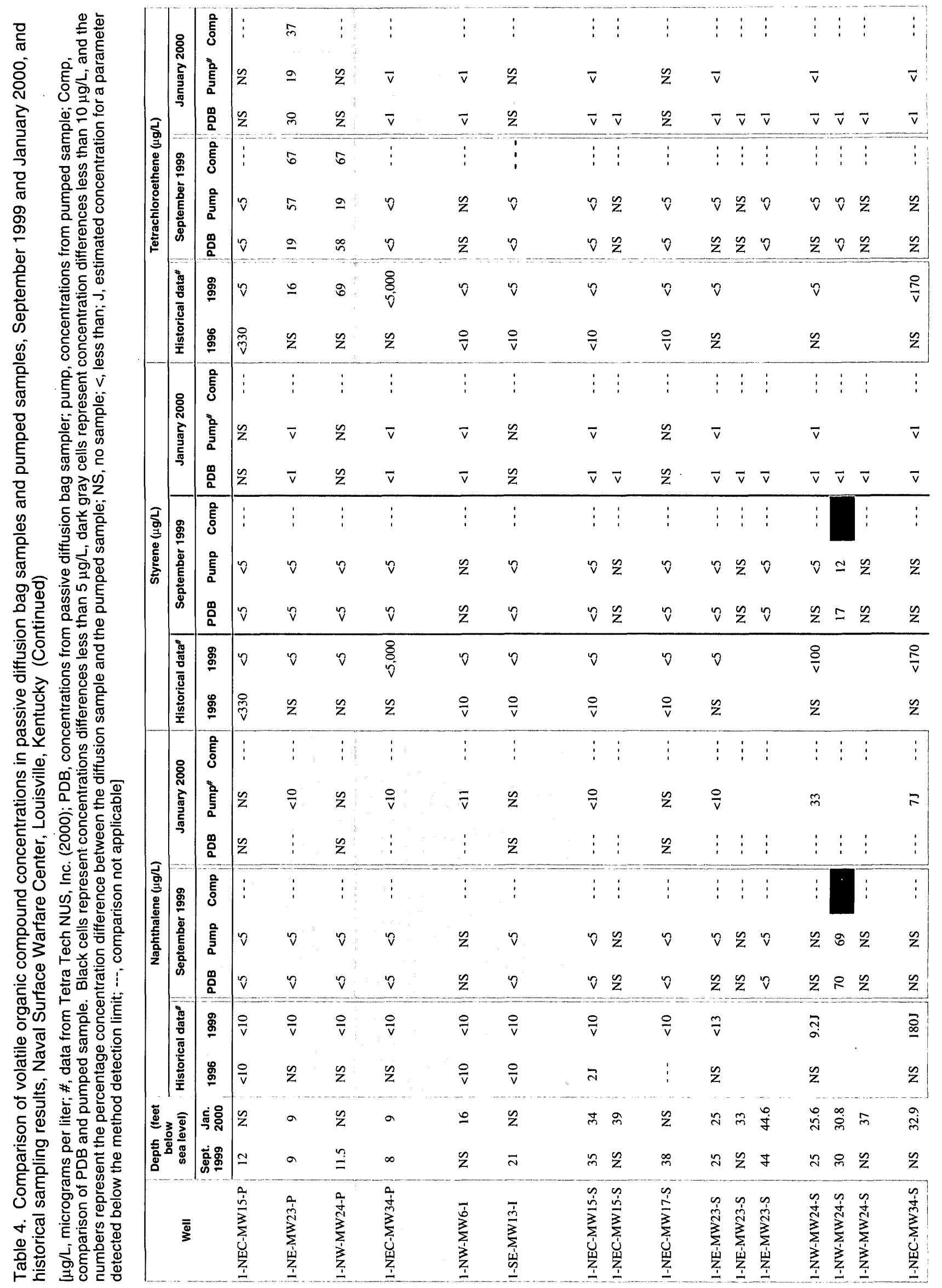




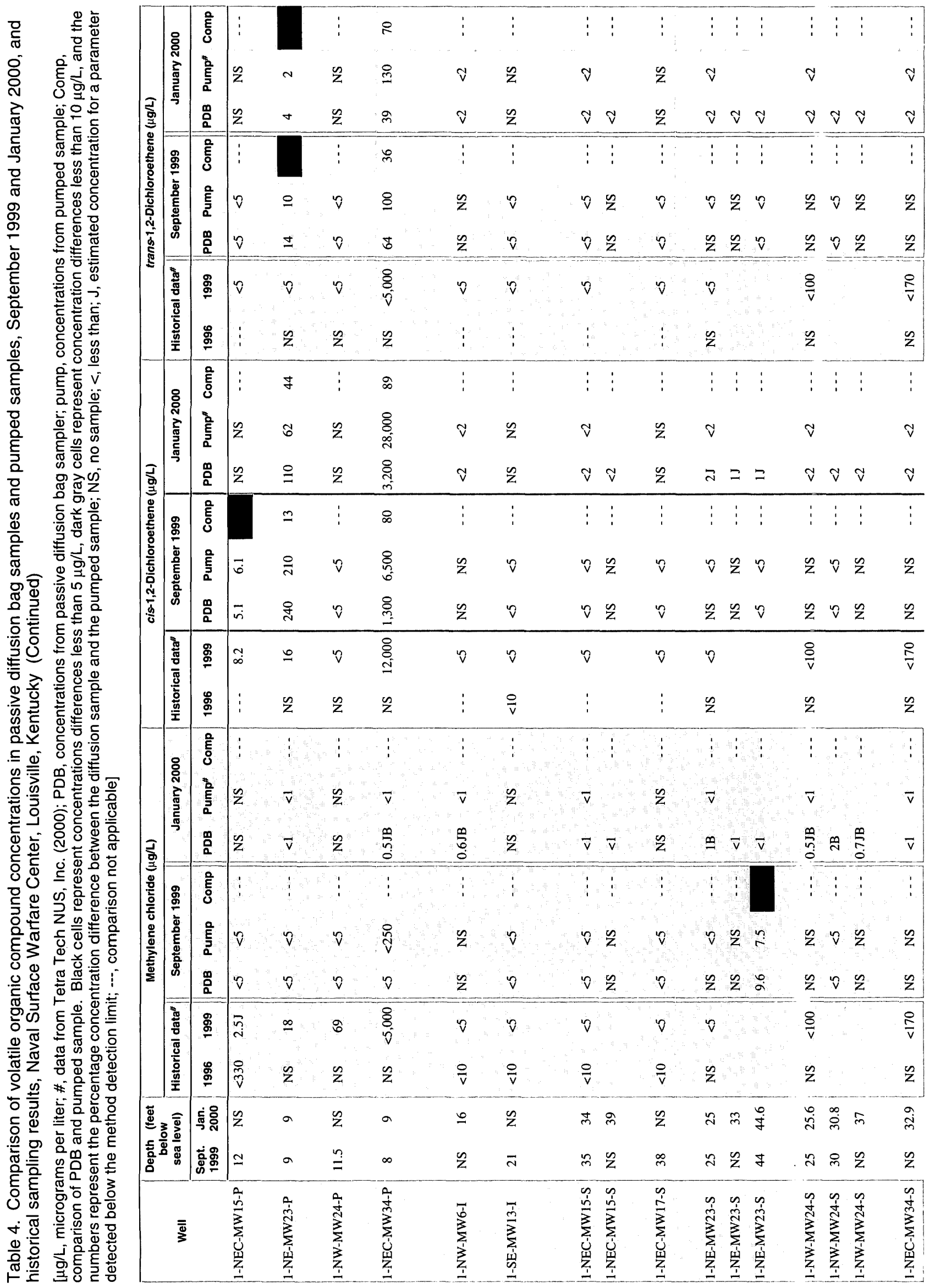

10 Evaluation of Passive Diffusion Bag Samplers in Selected Wells at the Naval Surface Warfare Center, Louisville, Kentucky, July 1999 to January 2000 


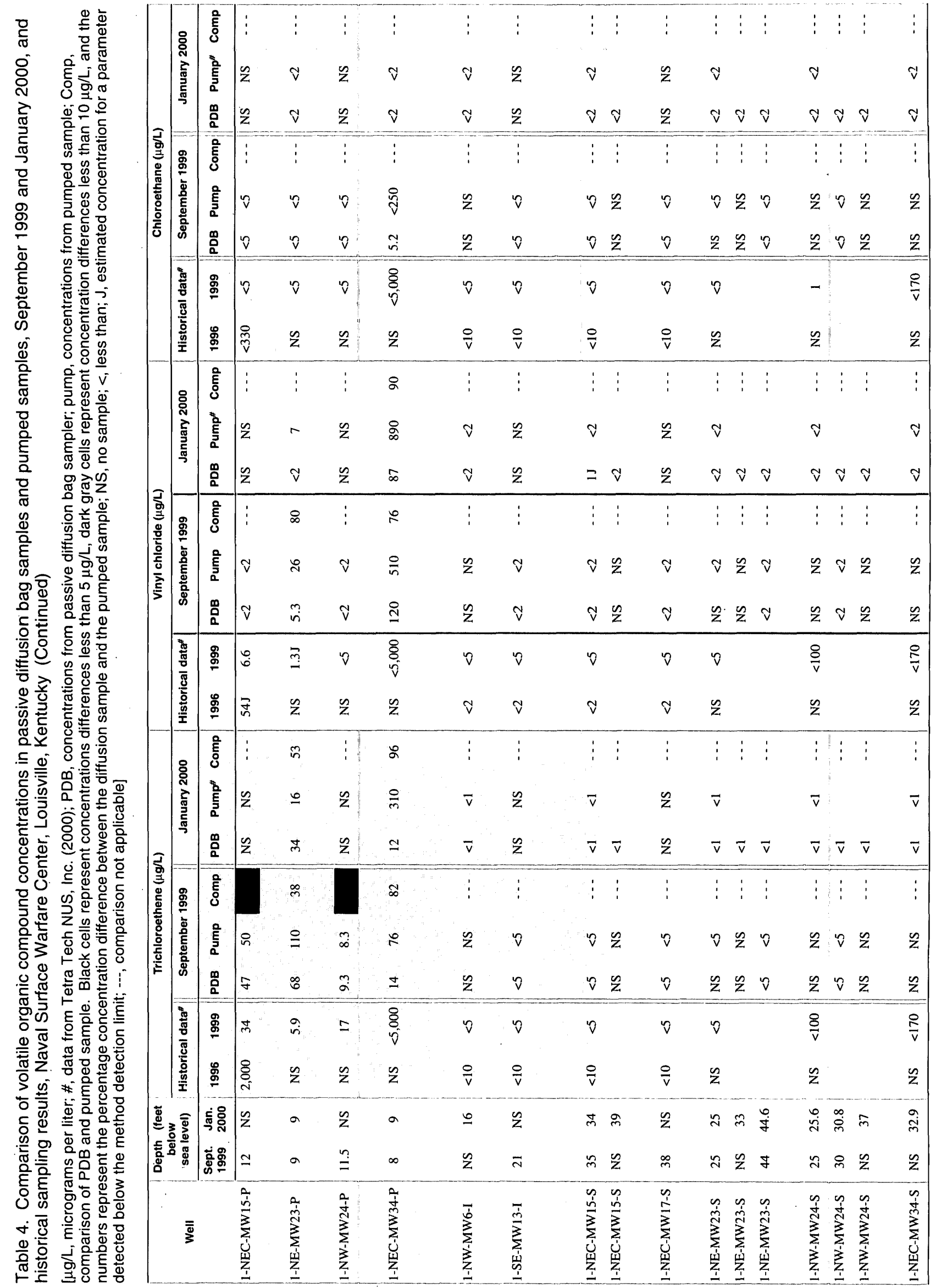


The PDB sampler slightly underestimated the 2-butanone concentration in ground water at well 1-NEC-MW17-S, but this does not seem to be an inability of the PDB sampler to quantify that compound because a close match between PDB-sample and pumped-sample 2-butanone concentrations was obtained at well 1-NE-MW23-S (table 4). The data suggest that the use of PDB samplers provide a viable alternative to collecting pumped samples in these wells.
The PDB-sampler data from well 1-NW-MW24-S (table 4) seem to be more representative of formation water than the pumped-sample data, despite the relatively large concentration differences between methods. The PDB-sampler data strongly suggest that contaminant stratification is present in the screened interval of the well (fig. 2). Although the VOC concentrations from the pumped sample and the adjacent PDB sample differ substantially in ground water from well 1-NW-MW24-S, the pumped-sample results for

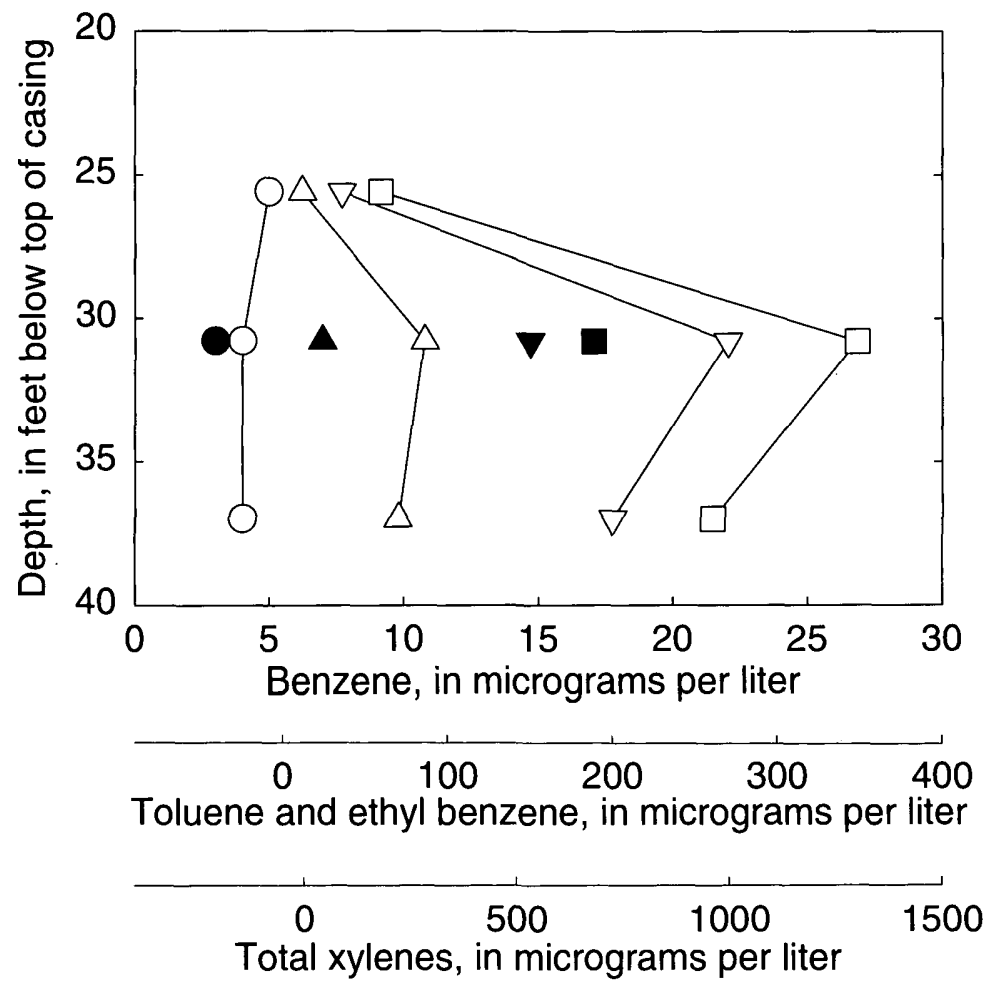

Figure 2. Comparison of benzene, toluene, ethyl benzene, and total xylenes concentrations in passive diffusion bag (PDB) samplers and in pumped samples, well 1-NW-MW24-S, Naval Surface Warfare Center, Louisville, Kentucky, January 2000. 
most compounds are within the range found by using the PDB samplers. The data suggest that the PDB samplers in well 1-NW-MW24-S reveal the contaminant stratification, and the pumped sample produces a mixed sample that incorporates water from both the lightly contaminated and heavily contaminated horizons (fig. 2). Moreover, although methyl-tert-butyl ether (MTBE) is not a compound recommended for use with PDB samplers because of the potential to underestimate actual concentrations (Vroblesky, 2001), the PDB samples from well 1-NW-MW24-S contained higher MTBE concentrations than the pumped sample. These data suggest that the PDB samplers provided a more accurate MTBE sample than the pumped sample. Thus, PDB samplers seem to be a viable alternative to collecting pumped samples in this well.

At well 1-NE-MW23-S, the two sampling methods did not agree; the PDB sampler produced higher VOC concentrations, suggesting that the PDB sampler more accurately revealed the higher concentrations than the pumped sample. In well 1-NE-MW23-S, the January 2000 pumped-sample data show no detectable contaminant concentrations. The PDB-sample data, however, show stratified contamination (table 4), with the lowest concentrations in the upper vuggy limestone and the highest concentrations near the bottom of the screened interval. Because well 1-NEMW23-S contained a 20-ft saturated screened interval (table 2), it is highly probable that the screen transects zones of differing contaminant concentration. Thus, the PDB data from this well seem to more precisely define the contaminant concentrations than the pumped samples, which probably represent uncontaminated water or a mixture of contaminated and uncontaminated water with resulting low or undetectable VOC concentrations.

Well 1-NW-MW24-P also is a well in which the two methods did not agree; the PDB sampler produced higher VOC concentrations than the pumped sample. Unlike well 1-NE-MW23-S, well 1-NW-MW24-P contained only about $1 \mathrm{ft}$ of saturated screened interval. The small saturated interval suggests the possibility that the PDB samplers may have been partly out of the water column. Further concern regarding the PDB sampler is that the aquifer at the well is low yielding. Pumping the well to collect samples essentially dried up the well, and only 2 in. of water were in the well by the next day, indicating poor recovery. Despite this, the fact that the PDB sampler produced higher VOC concentrations than the pumped sample implies that the
PDB sampler produced more representative concentrations. The low aquifer permeability and the potential for partial exposure of the PDB samplers to unsaturated conditions suggests the possibility that both sampling methods underestimated actual local VOC concentrations, but that the PDB sampler produced more realistic concentrations than the pumped sample in this well.

Well 1-NEC-MW34-S is another well in which the results of the two methods did not agree for most detected compounds, and the PDB sampler produced the higher concentrations (table 4). In this case, however, there is some uncertainty in the results because the sample was lowered through a layer of LNAPL. The effect of such a layer has not been thoroughly tested, and carryover from product sorbed to the polyethylene may have artificially produced higher than local concentrations in the PDB sampler. Future PDB tests in this well could be performed more confidently by using a method described in Vroblesky and Peters (2000) in which a capped pipe is lowered through the product, the cap is then removed with a rod and recovered by means of a line attached to the cap outside of the pipe; the PDB samplers then are lowered through the pipe past the product and into the well.

Despite the poor yield of the aquifer at well 1-NEC-MW15-S, the analytical data showed a good match at one or more depths between sampling methodologies for all detected contaminants (benzene, 2-butanone, toluene, and ethyl benzene) except total xylenes (table 4). Total xylenes concentrations differed by up to 76 percent, with the PDB samplers underestimating the concentrations. The reason for this difference, even though all of the other compounds closely match, is not clear. One concern is that well 1-NEC-MW15-S is screened in a poorly permeable zone. In September 1999, after pumping the well slowly ( $78 \mathrm{~mL} / \mathrm{min})$ for 1 hour and 42 minutes, the water level in the well continued to draw down, indicating that the pumped water probably was derived from storage in the well rather than from the aquifer. The poor exchange of water between the aquifer and the well screen may account for the difference in total xylenes concentrations between the two methods. However, even the pumped sample may not be representative of the aquifer concentrations because of poor yield. Alternatively, because the diffusion samplers were spread out over only $5 \mathrm{ft}$ of the $10-\mathrm{ft}$ saturated well screen (table 2), the PDB samplers may not have fully characterized the stratification. Higher total 
xylenes concentrations may be present at depths within the screened interval other than the PDB-samplertested depths. Thus, although the data imply that the use of PDB samplers in well 1-NEC-MW15-S can provide benzene, 2-butanone, toluene, and ethyl benzene concentrations similar to those obtained by pumping, questions remain regarding confident quantification of total xylenes and whether even the pumped sample is representative of formation concentrations.

A second well, 1-NE-MW23-P, showed mixed or ambiguous test results when PDB-sampler results were compared to pumped-sample results. The results from the September 1999 and January 2000 sampling events showed a close trans-1,2 dichloroethene concentration match between the methods (the differences between the methods ranged from 2 to $4 \mu \mathrm{g} / \mathrm{L}$ ); however, the concentration difference between the remaining detected compounds ranged from 13 to 80 percent. The PDB sampler provided higher concentrations than the pumped sample for some of the detected compounds (benzene, cis-1,2-dichloroethene, and trans1,2-dichloroethene) during the first sampling and for all of the detected compounds except vinyl chloride during the second sampling. The uncertainty in deciding whether the PDB sampler provided a viable alternative sampling method in this well lies in the fact that the pumped sample collected higher concentrations of tetrachloroethene ( 67 percent), trichloroethene (38 percent), and vinyl chloride ( 80 percent) than the PDB sampler during the September 1999 sampling.

A possible explanation for the differences between the methods at well 1-NE-MW23-P lies in the probability of chemical stratification in the screened interval. Although there was only about 4.89 to $5 \mathrm{ft}$ of saturated interval in this well during sampling (table 2), sampling observations indicate the presence of a sharp chemical gradient. During the September 1999 sampling, after purging only 2 gal of water from the bottom of the well, the discharging water contained only a low amount of dissolved oxygen [0.7 millgrams per liter $(\mathrm{mg} / \mathrm{L})$ ]; however, after purging $4 \mathrm{gal}$, the discharging water contained substantially more dissolved oxygen $(2.5 \mathrm{mg} / \mathrm{L})$. These results suggest that there is a thin zone of anaerobic water near the base of the screened interval and an oxygenated zone near the top of the screened interval that became increasingly mixed during pumping. Support for this hypothesis is the observation that the bottom part of the rope connected to the PDB sampler was stained black, suggesting deposition of reduced sulfur or iron species in an anaerobic environment (dissolved oxygen data and physical observations are not available for the January 2000 sampling). The presence of redox stratification, as suggested here, may also indicate chlorinated solvent stratification. If such stratification is present and is of a finer scale then the length of the PDB sampler, then the VOC concentrations in the PDB sampler also may be stratified, resulting in a mixed concentration within the sampler and possibly producing results that underestimate concentrations in the small stratified zone. In addition, the concentrations in the pumped sample may vary depending on the position of the pump inlet relative to the stratification and the length of pumping time prior to sample collection. If a pumped sample is used to obtain these data, then care should be taken to pump a consistent volume of water prior to sampling to increase the comparability of data among sampling events.

In one well (1-NEC-MW34-P), the PDB sampler provided a poor comparison to the pumped sample. Although benzene concentrations showed a close match between sampling methods, the concentrations of most of the remaining detected compounds were substantially lower in the PDB sampler (by $36-96$ percent) than in the pumped sample.

Three possible explanations can be postulated for the difference. (1) The PDB sampler may have been partially exposed above the water table prior to the sampling events because there was only 2.65 to $2.83 \mathrm{ft}$ of saturated screened interval during the sampling events (table 2). (2) Because of the small saturated interval, the rate of volatilization loss in the wellbore may have exceeded the rate of VOC exchange with the aquifer, resulting in concentrations in the wellbore not representative of the aquifer. (3) It is possible that the contributing zone of contaminant was small relative to the size of the diffusion sampler, in which case the PDB sampler may have averaged concentrations, whereas much of the water sampled by the pump may have been derived directly from the contributing zone. For well 1-NEC-MW34-P, the simplest resolution is to continue sampling the well by purging. Alternatively, if the use of a PDB sampler is desired, then further testing at the well should be done with a shorter PDB sampler.

In the wells where multiple PDB samplers were used to evaluate the vuggy limestone (wells 1-NECMW15-S and 1-NW-MW24-S), the PDB-sampler data supported the findings from colloidal borescope data, indicating that the vuggy limestone was not a zone that supplied water to the wells (Aqua VISION, 1999). 
The PDB-sampler data showed lower VOC concentrations adjacent to the vuggy limestone and higher VOC concentrations deeper in the limestone.

Analysis of the ground-water sampling data show that both the PDB samplers and the pumped samples from 2 of the 11 tested wells (wells 1-NWMW6-I and 1-SE-MW13-I) contained no detectable contaminant concentrations except for estimated concentrations (J values) (table 4) below the detection limit of methylene chloride and 2-butanone in the PDB sample from well 1-NW-MW6-I.

\section{SUMMARY}

PDB samplers were tested in 11 wells at NSWC Louisville, Ky., by comparing the VOC concentrations obtained from PDB samplers to VOC concentrations obtained by pumping the wells. Despite the poorly permeable nature of the fractured-rock aquifer at the site, several of the tested wells showed a good comparison between VOC concentrations obtained from the PDB samplers and VOC concentrations obtained by using a pump. The comparison between the PDB sampler and the pumped sample was considered acceptable if the concentrations for particular contaminants agreed within $10 \mu \mathrm{g} / \mathrm{L}$, or within 10 percent, or the concentration in the PDB sample was higher than in the pumped sample. Five of the tested wells (wells 1-NEC-MW15-P, 1-NEC-MW17-S, 1-NE-MW23-S, 1-NW-MW24-S, and 1-NW-MW24-P) contained detectable contamination and showed a relation between the PDB-sampler results and the pumped-sample results suggesting that the PDB-samplers accurately reflected ambient contaminant concentrations.

In two wells where the data suggest that the PDB samplers produced the more representative results (wells 1-NE-MW23-S and 1-NW-MW24-P), VOC concentrations from the two methods did not agree; the PDB sampler produced the higher concentrations. The concentration differences in well 1-NWMW23-S probably are attributable to low values resulting from mixing of stratified waters during pumping. In well 1-NW-MW24-P, the PDB sampler produced higher concentrations than the pumped sample despite a short saturated interval (about $1 \mathrm{ft}$ ) and a low-yielding aquifer. The PDB sampler and the pumped sample both may have underestimated actual concentrations, but the data suggest that the PDB sampler produced more realistic concentrations than the pumped sample in this well. In a third well where the PDB sampler produced higher concentrations than the pumped sample (well 1-NEC-MW34-S), it is unclear whether the PDB sampler produced the more representative results or whether the higher concentrations in the PDB sampler were the result of carryover after having passed through a layer of light non-aqueous-phase liquid during deployment.

The data from well 1-NEC-MW15-S showed a good match between sampling methodologies for all detected contaminants (benzene, 2-butanone, toluene, and ethyl benzene), but a poor match for total xylenes. It is unclear why the xylene concentrations differed substantially whereas concentrations of all the other compounds closely matched. Explanations include the possibility that neither method adequately represents ambient conditions in this well because of poor exchange of water between the aquifer and the well screen in this low-yielding well. Alternatively, the PDB samplers may not have fully characterized the stratification because the diffusion samplers were spread out over only $5 \mathrm{ft}$ of the 10 -ft saturated well screen. Higher total xylenes concentrations may be present at depths within the screened interval other than the PDB-sampler-tested depths or in an area not adjacent to the screened interval and transported to the well by pumping during well purging and sampling. Thus, although the data imply that the use of PDB samplers in well 1-NEC-MW15-S can provide benzene, 2-butanone, toluene, and ethyl benzene concentrations similar to those obtained by pumping, questions remain regarding confident quantification of total xylenes and whether even the pumped sample is representative of formation concentrations.

Similarly, well 1-NE-MW23-P showed a close match between the two methods for trans-1,2 dichloroethene concentrations in September 1999 and January 2000; however, there were differences between the methods for other detected compounds. Geochemical evidence indicates the presence of redox stratification in the saturated interval of this well, which may also indicate chlorinated solvent stratification. If so, then the VOC concentrations in the PDB sampler represent an average over the length of the sampler, and the concentrations in the pumped sample may vary depending on the depth of the pump and the length of pumping time prior to sample collection. Under these conditions, the use of a PDB sampler at a specific target horizon may provide concentrations representative of local conditions. If a pumped sample is used to obtain these data, then care should be taken to pump a consistent volume of water prior to sampling to increase the comparability of data among sampling events. 
In one well (1-NEC-MW34-P), the PDB sampler provided a poor comparison to the pumped sample. Possible explanations include partial exposure of the sampler above the water table, volatilization loss from the wellbore at a rate faster than the exchange with the aquifer, or contaminant inflow to the well through a smaller zone than the length of the sampler, resulting in an underestimate of actual concentrations. For well 1-NEC-MW34-P, the simplest resolution is to continue sampling the well by purging. Alternatively, if use of a PDB sampler is desired, then further testing at the well should be done with a shorter PDB sampler.

In the wells where multiple PDB samplers were used to evaluate the vuggy limestone (wells 1-NECMW15-S and 1-NW-MW24-S), the PDB-sampler data supported the findings from colloidal borescope data indicating that the vuggy limestone was not a zone that supplied water to the wells. The PDB-sampler data showed the lowest VOC concentrations adjacent to the vuggy limestone and higher VOC concentrations deeper in the limestone.

Analysis of the ground-water sampling data show that both the PDB samplers and the pumped samples from 2 of the 11 tested wells (wells 1-NWMW6-I and 1-SE-MW13-I) contained no detectable contaminant concentrations except for low concentrations of methylene chloride and 2-butanone in the PDB sample from well 1-NW-MW6-I.

\section{REFERENCES}

Aqua VISION, 1999, Colloidal borescope investigation at the Naval Ordnance Station, Crane Division, Naval Surface Warfare Center (NSWC), Louisville, Kentucky: Consultant's report to Southern Division Naval Facilities Engineering Command, May 19, 1999, 12 p.

Environmental Liability Management, Inc., 1999, Hydrocarbon characterization, Naval Ordnance Station, Louisville, Kentucky: Letter report to Dave Olson, TetraTech NUS, Inc, Gaithersburg, Md, June 19, 1999, 3 p.

Tetra Tech NUS, Inc., 2000, RCRA Facility Investigation Volume 1, Book 2, Naval Ordnance Station Crane Division, Naval Surface Warfare Center, Louisville, Kentucky: Consultant's report to Southern Division Naval Facilities Engineering Command, September 2000, 176 p.

U.S. Environmental Protection Agency, 1999, On-line SW-846 methods: Accessed December 21, 1999, at URL www.epa.gov/epaoswer/hazwaste/test/ tx8xxx.htm\#8XXX.

Vroblesky, D.A., 2001, User's guide for polyethylene-based passive diffusion bag samplers to obtain volatile organic compound concentrations in wells: Part 1: Assembly and quality control and assurance: U.S. Geological Survey Water-Resources Investigations Report 01-4060, $18 \mathrm{p}$.

Vroblesky, D.A., and Hyde, W.T., 1997, Diffusion samplers as an inexpensive approach to monitoring VOCs in ground water: Ground Water Monitoring and Remediation, v. 17 , no. 3 , p. 177-184.

Vroblesky, D.A., and Peters, B.C., 2000, Diffusion sampler testing at Naval Air Station North Island, San Diego County, California, November 1999 to January 2000: U.S. Geological Survey Water-Resources Investigations Report 00-4182, 27 p. 
定 $\frac{\text { m }}{\text { 至. }}$

조 음

궁

है

定

至

के

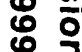

0

ํํ

以

疍

ง

용

亏

83 Printed on recycled paper 